\title{
Transcription Factor E2F1
}

National Cancer Institute

\section{Source}

National Cancer Institute. Transcription Factor E2F1. NCI Thesaurus. Code C17546.

Transcription factor E2F1 (437 aa, $\sim 47 \mathrm{kDa}$ ) is encoded by the human E2F1 gene. This protein is involved in the regulation of apoptosis, gene transcription, cell cycle progression and cell proliferation. 